\title{
Cavitary Pulmonary Tuberculosis Masquerading as a Whoopy Cough in a Neonate
}

\author{
Vivek Kumar* \\ Army Hopsital Research and Referral, Dhaula kuan, India
}

Submission: July 01, 2017; Published: January 19, 2018

*Corresponding author: Vivek Kumar, Army Hopsital Research and Referral, Dhaula Kuan, New Delhi-110010, India, Tel: 7042743322, Email: vk3532@gmail.com

\begin{abstract}
Cavitary Tuberculosis in an adult, a common entity, presents as post primary tuberculosis. Its presentation as primary cavitary tuberculosis (PCT) in young infants is rare and in a neonate it's not even reported. PCT is a devastating disease with serious consequences if not promptly and adequately treated. We report a case in a preterm infant, first of the twins, who became symptomatic early in life with whoopy cough and finally turned out to be PCT associated with military tuberculosis. She had a favourable response to the first line antituberculous drugs.
\end{abstract}

\section{Introduction}

PCT in young infants is a rare entity and even more so in a preterm neonate. It happens because of caseating necrosis in the primary lesion and its extrusion through the bronchus. It is more common on the right side [1]. In a series of 75 patients of PCT reported by Maniar [2] youngest patient he had reported was 1.5 months with an average age of presentation being 7-12 months. We report a preterm neonate on isoniazid prophylaxis, first of the twins born to a mother with proven TB on ATT (Antituberculosis Treatment), presenting with a whoopy cough. She was diagnosed both radiologically and bacteriologically as PCT with military tuberculosis. She was treated successfully without any complications.

\section{Case Report}

28 days old female infant first of the twins born at 35 weeks period of gestation with a birth weight of $1.8 \mathrm{~kg}$ through Lower Segment Cesarean Section was brought with complaints of incessant whoopy cough, breathlessness and failure to thrive which had started at 20 days of life. Antenatally mother was detected to be sputum positive pulmonary tuberculosis and was started on ATT at 32 weeks of pregnancy. Mother was sputum negative at the time of delivery. Both the neonates were started on INH prophylaxis at birth, chest X-ray at birth was normal. Clinically her weight was $2.0 \mathrm{Kg}\left(<10^{\text {th }}\right.$ centile), Occipito frontal circumference was $36 \mathrm{~cm}\left(95^{\text {th }}\right.$ centile) and her length was $48 \mathrm{~cm}$ ( $75^{\text {th }}$ centile). Temperature was 100 degree Fahrenheit, respiratory rate was 64 /minute, pulse was $140 /$ minute, oxygen saturation was $91 \%$ in room air reaching to $99 \%$ with oxygen. BCG uptake was present. There were diffuse crepitations and rhonchi all over the chest. There was no organomegaly.

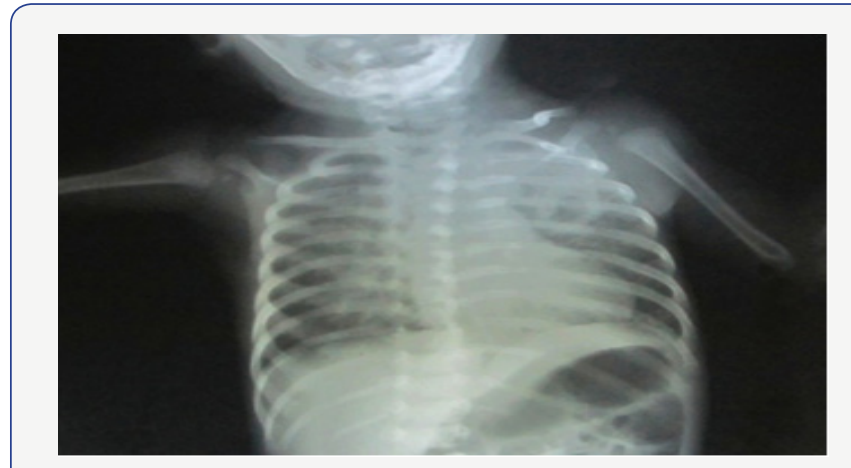

Figure 1: Chest X-ray Showing Cavity lesion left upper zone with military seedling bilaterally.

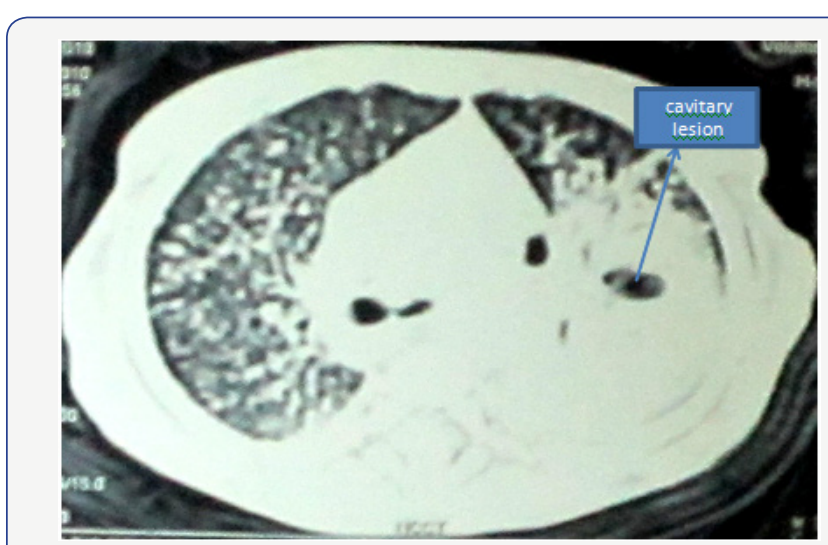

Figure 2: NCCY chest showing left upper zone consolidation with cavitary lesion with military seedling bilaterally.

Patient was evaluated her hemogram showed hemoglobin of $11 \mathrm{gm} \%$, counts were normal. ESR was $30 \mathrm{~mm}$ at 1 hour. Chest radiograph showed thick walled cavity in upper zone of left lung 
with military mottling bilateral (Figure 1). Mantoux was $18 \mathrm{~mm}$ at 72 hours. Biochemical parameters were normal. Ultrasound of the abdomen was normal. Cerebrospinal fluid analysis revealed no abnormality. NCCT Chest scan revealed consolidation with cavitatory lesion of upper lobe of left lung with military seedling (Figure 2). Mycobacterium tuberculosis was detected in gastric aspirate. Infant who was initially strated on empirical antibiotics was switched to four drugs ATT with isoniazid, rifampicin, pyrazinamide and ethambutol daily for two months followed by isoniazid and rifampicin for next four months. After six months of treatment the baby recovered clinically and radiologically other sibling did not have any complications.

\section{Discussion}

The rarity of cavitary tuberculosis in infants, the non-specific nature of the symptoms and associated clinical signs of tuberculosis in early infancy have been repeatedly commented upon in the literature with congenital tuberculosis [3-8]. In the present case, despite the positive history in mother and child on isoniazid prophylaxis, tuberculosis was not suspected at first and baby was given antibiotics. A similar sequence has been reported by Chou et al. [9].Was the infection congenital or acquired perinatally could not be answered, as both can present with bronchopneumonia, miliary mottling, upper and mid zone pneumonia, interlobulitis, or reticulonodular infiltrations. Congenital tuberculosis infections tend to be diffuse rather than localized as also described by Choudhary [10] in a 52 day old neonate. In this case absence of extra pulmonary disease despite having miliary seedling in the lungs made us speculate that the infection was acquired at or near the time of birth, though the presence of cavitary pulmonary tuberculosis at only 28 days is remarkable. Endometrial biopsy in the mother would have identified timing and source of infection and guided us in initiating early treatment [11].

\section{References}

1. Aderele WL (1980) Radiological patterns of pulmonary tuberculosis in Nigerian children. Tubercle 61(3): 157-163.

2. Bansari M (1994) Cavitating pulmonary tuberculosis in children less than 2 years of age. Indian Pediatric 31: 181-190.

3. Harris VJ, Duda F, Langer SS, Schauf V (1977) Cavitatory tuberculosis in children. J Pediatri 90(4): 660-661.

4. Smith KC (2002) Congenital tuberculosis: a rare manifestation of common infection. Curr Opin Infect Dis 15(3): 269-274.

5. Hageman J, Shulman S, Schreiber M, Luck S, Yogev R (1980) Congenital tuberculosis: critical reappraisal of clinical findings and diagnostic procedures. Pediatrics 66(6): 980-984.

6. Myers JP, Perlstein PH, Light IJ, Towbin RB, Dinscoy HP, et al. (1981) Tuberculosis in pregnancy with fatal congenital infection. Pediatrics 67(1): 89-94.

7. Nemir RL, O'Hare D (1985) Congenital tuberculosis. Review and diagnostic guidelines. Am J Dis Child 139(3): 284-287.

8. Save S, Doshi H, Somale A (2012) Lung cavities in an infant: Could it be tuberculosis? J Postgrad Med 58(3): 213-214.

9. Chou YH (2002) Congenital tuberculosis proven by percutaneous liver biopsy: report of a case. J Perinat Med 30(5): 423-425.

10. Choudhary J, Mubarik M, Parvez A, Naikoo MA (2004) Cavitatory pulmonary tuberculosis in a 52-day-old infant. J R Soc Med 97(3): 127128.

11. Balaka B, Bakondi B, Boko E, Boko E, Adjenou K, et al. (2002) Tuberculosis in newborns in a tropical neonatology unit. Arch Pediatr 9(11): 1156-1159.

\section{Your next submission with Juniper Publishers will reach you the below assets}

- Quality Editorial service

- Swift Peer Review

- Reprints availability

- E-prints Service

- Manuscript Podcast for convenient understanding

- Global attainment for your research

- Manuscript accessibility in different formats

( Pdf, E-pub, Full Text, Audio)

- Unceasing customer service

Track the below URL for one-step submission https://juniperpublishers.com/online-submission.php 